\title{
Detection of White Spot Syndrome Virus in Cultured Penaeid Shrimp using Histopathological Observation and Polymerase Chain Reaction
}

\author{
El-Shahidy M.S ${ }^{1}$, El-Gamal R.M ${ }^{2}$, Amina A. Dessouki ${ }^{3}$, Randa Y. \\ Thabet, Shahira A. Abdelwahab ${ }^{1}$, Abd-Eldaim M.M ${ }^{1}$ \\ ${ }^{1}$ Department of Virology and ${ }^{2}$ Department of Pathology, Faculty of \\ veterinary Medicine, Suez Canal University ${ }^{3}$ Fish health and management \\ department, Central Laboratory for aquaculture research, Agricultural \\ Research Center, Abbassa
}

\begin{abstract}
White spot syndrome virus (WSSV) in Egyptian shrimp is poorly understood and there is no available information regarding possible WSSV infection of native shrimp in Egypt. Therefore, the main goal of this work was to diagnose WSSV in Egyptian shrimp by histopathological examination and molecular based methods (PCR). A total of 90 shrimp samples showed circular white patches in the cuticle were collected from the local fish markets of high shrimp producing region in three provinces of Egypt. The three regions located at the south coast of Mediterranean Sea, including El-Arish, Dumiatta and Kafr El-sheikh. Histopathological examination of different organs showed intranuclear basophilic inclusion bodies. Single-step PCR results with primers specific for the gene encoding VP28 gave a predicted amplified product at $677 \mathrm{bp}$. The primer pair designed from WSSV genomic sequence yields a 677 bp fragment by agarose gel electrophoresis.
\end{abstract}

Key words: shrimp, Egypt, whit spot syndrome virus, PCR, histopathology

\section{Introduction}

Shrimp are important food sources for human consumption and play a major role in food chain. Commercial shrimp species support an industry worth 50 billion dollars a year (Rudloe \& Rudloe, 2009).

The global shrimp production showed a declining trend from 1994 to 1997 , (Rosenberry, 2001). In
India, the production rate was found to decline from 1994 to 1997 (Pillai and Katiha, 2004) and in Asian countries, the value was found declined from 1997 to 1998 (FAO, 2008). This declining trend was mainly attributed to disease caused by white spot syndrome virus (Lightner, 2003). 
White spot syndrome virus (WSSV) was first reported at shrimp farms in northern Taiwan in 1992 (Chou et $\boldsymbol{a l}, \mathbf{1 9 9 5 )}$ and has been found worldwide within a decade (EscobedoBonilla et al, 2008). The WSSV causes serious economic losses because of $100 \%$ mortality leading to total crop losses within 3-10 days under some farming conditions (Pradeep, 2009).

The virus is the only member of the family Nimaviridae, genus Whispovirus (Mayo, 2002). WSSV is an enveloped; double stranded circular DNA virus, ovoid to bacilliform in shape with a tail like extension at one end (van Hulten et al, 2001a; Yang et al, 2001). WSSV is pathogenic to at least 78 species, mainly to decapod crustaceans including marine and fresh water shrimp, crab, crayfish and lobsters (Lightner, 1996 ; Flegel, 2006).

In Egypt, shrimp industry are steadily progressed to meet the market demands specially in the coastal area, but the high risk of virus infection in shrimp farms might be affect the production (Eissa et al, 2009). WSSV in Egyptian shrimp are poorly understood. To our knowledge, there is no available information regarding possible WSSV infection of native shrimp in Egypt. Therefore, the main goal of this work was to diagnose WSSV in Egyptian shrimp by histopathological examination and molecular based methods (PCR).

\section{Materials and methods}

A total of 90 shrimp samples showed circular white patches in the cuticle were collected from the local fish markets of high shrimp producing region in three provinces of Egypt (30 shrimp/ each region). The three regions located at the south coast of Mediterranean Sea. The first region is Ezbit El-Borg, Dumiatta province in which Farawla shrimp (Penaeid Aristeus antennatus) is the most dominant species in the market. The second region is Al-Areesh, Nourth Sinai province in which Gazaz shimp (Penaeid japonicus) is the most dominant shrimp species in the market. The last third region is AlBurlis city located at Al-Burlis Lake, Kafr El-Sheikh province in which the white shrimp (Penaeid semisulacatus) is the most dominant shrimp species.

\section{Histopathological examination}

Cut sectioning passing through the cuticle, gills, heart, hepatopancreas, lymphoid tissues, stomach and gut were taken and fixed in Davidson solution (pH 3.5 to 4), according to Vijayan and alavandi (2005). Tissues were processed and histopathological section were prepared and stained with $\mathrm{H} \& \mathrm{E}$ according to the protocol of (Bell and Lightner, 1988)

\section{Shrimp samples for PCR}

All collected shrimp were cleaned, washed three times in sterile distilled water and dried thoroughly with sterile towels before exposure 
for anatomy and collection of internal organs. The cuticle of moribund shrimp as well as control shrimp were split sagittally using a surgical scalpel and scissors. A part of gills, stomach, hepatopancreas, gut, heart, muscle and cuticle are kept in separate containers at $-20^{\circ} \mathrm{C}$ for DNA extraction and diagnosis of white spot syndrome virus in clinical samples with PCR.

\section{DNA extraction kits}

Total DNA of shrimp tissues were extracted by following the manufacturer instructions of the extraction Kits (Konrad Cres Marham on L3R 8T4 Canada - Ez10 Genomic DNA Kit Handbook).

\section{Gene amplification reaction} conditions for WSSV VP28 gene

Oligonucleotide Primers were as follows according to (Van Hulten et al, 2001):

VP28

$$
\text { vp28F }
$$

5 ,

CGACATCTTAATAACCAAGCA ACG 3'; VP28 vp28R 5' AAAAGCACGATTTATTTACTC GG 3'. That was targeting (677 bp) the complete ORFs of structural viral proteins of WSSV VP28. Briefly, the homogenate was mixed with SNET lysis buffer $(20 \mathrm{mM}$ Tris-HCl, $\mathrm{pH} 8.0 ; 5$ mMEDTA, $\mathrm{pH}$ 8.0; $400 \mathrm{mM} \mathrm{NaCl} ; 1 \%$ (w/v) SDS; $1 \mathrm{mg} \mathrm{ml-1Proteinase} \mathrm{K})$ and incubated for $8 \mathrm{~h}$ at $55^{\circ} \mathrm{C}$. The PCR mixture $(100 \mu \mathrm{l})$ contained $2 \mu \mathrm{g}$ of DNA, 100 pmol of each primer, $1 \times$

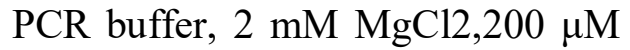
dNTP, and 2.5 units of Taq polymerase (PCRCore Kit, Boehringer). The PCR was performed according to the published protocol using My Cycler (Biorad) with an initial denaturation at $95^{\circ} \mathrm{C}$ for 5 minutes and followed by 30 cycles of denaturation at $94^{\circ} \mathrm{C}$ for 30 seconds, annealing at $60^{\circ} \mathrm{C}$ for 30 seconds and elongation at $72^{\circ} \mathrm{C}$ for 30 seconds. The PCR amplification was completed using a final elongation step at $72^{\circ} \mathrm{C}$ for 5 minutes then incubation at $4^{\circ} \mathrm{C}$.

\section{Gel electrophoresis}

Five microliters of PCR product in $5 \mu \mathrm{l} 1 \mathrm{X}$ TAE Buffer and $1 \mu \mathrm{l}$ loading Dye and $0.5 \mu 1$ of DNA Ladder in $9.5 \mu 11 \mathrm{X}$ TAE Buffer plus Dye were loaded into a $1.5 \%$ agarose gel with ethidium bromide and electrophoresed at $100 \mathrm{~V}$ for 30 - 32 minutes. The bands were viewed using U.V.Transllaminator (UVP, USA). Ten-fold serial dilutions of the genomic DNA were prepared to determine the sensitivity of the PCR assays.

\section{Results}

\section{Gross Pathology}

The affected shrimp of the three examined species showed loose and easily separated cuticle from the underlying epidermis with the presence of white spots on external surface. White spots appeared in carapace and cephalothorax and its sizes varied from pinpoint minute dots to spots of about $3 \mathrm{~mm}$ in diameter. These spots coalesced to each other forming patches of variable sized whitish circular spots. White spots mostly located on the inside surface of the cephalothorax and these spots can't be scraped-off. 
In case of Aristeus antennatus (Red Shrimp), the red color of the shrimp make the white spots more clearly and prominent Large (Figure 1-a, b, c \&d). Hepatopancrease become yellowish-white with swollen and fragile texture. Lymphoid tissue was swollen and shrunken, In addition to Swelling of bronchiostegites due to accumulation of fluid.

\section{Histopathological changes}

\section{Hepatopancreas}

Histopathological examination of hepatopancreatic tubules showed that the hepatopancreas suffering from vacuolization of the entire tissue. Hepatopancreas showed also degeneration, necrosis, with pyknotic nuclei (Figure 2-a).

\section{Heart}

Heart muscles showed generalized vacuolization, hyaline degeneration, increased infiltration of lymphocytes and oedema. The myocardial fibers showed intranuclear inclusion bodies (Figure 2-b).

\section{Gills}

The dendrobranchiate gill consisting of gill axis and the gill filament. The gill axis of affected shrimp showed massive disintegration and vacuolization in clinically affected specimens. The gill filaments in apparently healthy shrimps contained numerous lacunae occluded by hemocytes. During infection they showed massive disintegration and generalized vacuolization and the nuclei of the epithelial cells were hypertrophied. The nuclei of gill epithelium contained hypertrophy and prominent intranuclear basophilic inclusion bodies (Figure 2-c).

\section{Integument}

Cuticle of shrimp is the target organ and predilection site of WSSV replication. The outer exocuticle and the underlying procuticular layers of the integument were discernable in the affected cases. The underlying epidermis which secretes the integument showed massive necrosis and nuclear hypertrophy. The cuticular and subcuticular cells showed a prominent basophilic intranuclear inclusion bodies (Figure 2-d).

\section{Stomach}

Histopathological examination of stomach of affected shrimp showed hyperatrophy and hyaline degeneration in epithelium of the organ compared to normal cuticular epithelium and subcuticular connective tissues of shrimp stomach. Cuticular and subcuticular connective tissue cells showed intranuclear basophilic inclusion bodies (Figure 2-e).

\section{Hematopoietic tissues}

Hematopoietic tissues appeared to be the most affected. Multiple foci of pyknotic nuclei were present in the hematopoietic tissue. The lymphoid organs were hypertrophied and edematous. Large numbers of vacuoles were observed in the connective tissue among the lymphoid organ tubules. Some cells showed nuclear 
hypertrophy with esinophilic to basophilic intranuclear inclusion bodies (Figure 2-f).

III- PCR results of WSSV in shrimp samples

Single-step PCR results with primers specific for the gene encoding VP28 gave a predicted amplified product at $677 \mathrm{bp}$. The primer pair designed from WSSV genomic sequence yields a $677 \mathrm{bp}$ fragment by agarose gel electrophoresis as observed in (Figure 3). This PCR product was obtained from 6 WSSV samples that were previously suspected by gross lesions and histopathology as being infected with WSSV. These samples represent isolates from three geographic coastal locations in Egypt including El-Arish, Dumiatta and Kafr El-sheikh. The amplified PCR products in WSSV of infected shrimp samples of different species compared to the gross lesions and histopathology as shown in revealed that 3 out of 20 shrimp samples of $P$. japonicas were PCR positive. Mean while $P$. semisulcatus and $A$. antennatus showed two samples and only one sample out of 20 total samples which were positive respectively.

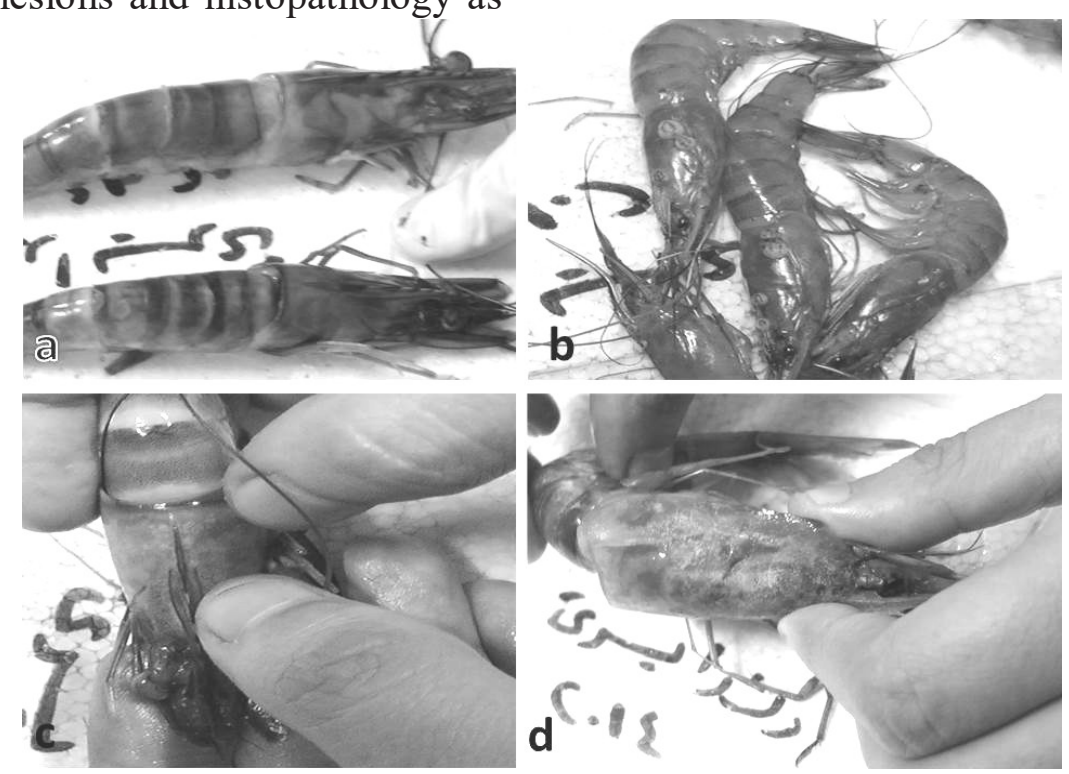

Figure 1-(a): Patches of variable sized coalescence whitish spots in P.japonicus. (b): White spots in cuticle of cephalothorax and body of P.semisulcatus shrimp. (c): White spots assembled in bead like row in cuticle of P.semisulcatus shrimp. (d): Coalesced large white spots in carapace of red shrimp. 


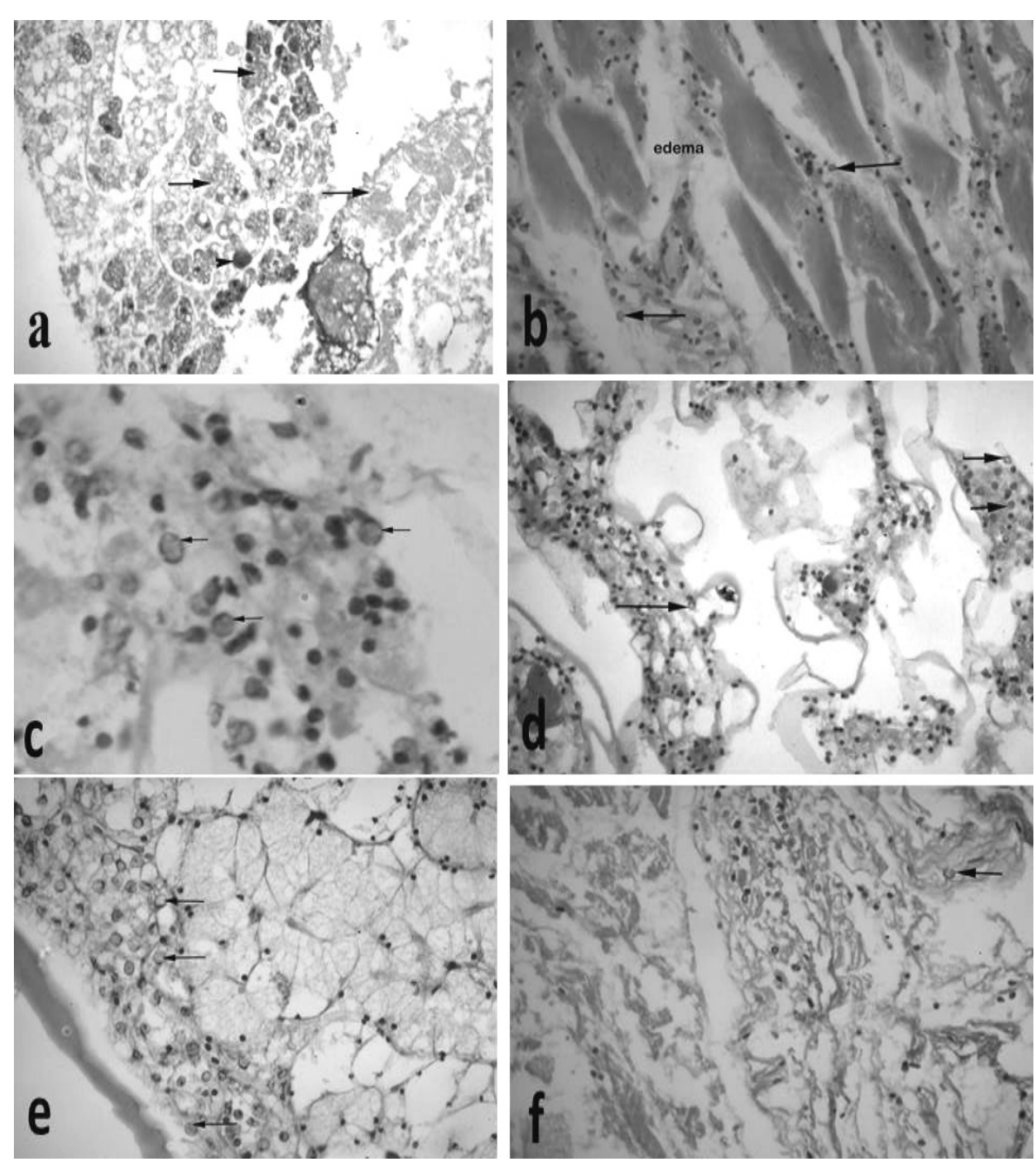

Figure 2: H\&E stained shriomp sections at 400X. (a) Hepatopancrease of Penaeus semisulcatus showing hepatopancreatic degeneration and necrosis (Arrows) and basophilic hypertrophied nuclei (arrow head). (b) Heart of Penaeus Japonicus showing intranuclear inclusion bodies (Arrows) and inter muscular edema. (c) Gills of Penaeus Japonicus showing basophilic intranuclear inclusion bodies (Arrows). (d) Gills of Aristeus antennatus showing intranuclear inclusion bodies (Arrows). (e) Stomach of Penaeus Japonicus showingintranuclear inclusion bodies (Arrows) in cuticular and sub-cuticular connective tissue. $(f)$ Connective tissue of Aristeus antennatus showing intranuclear inclusion bodies (Arrow) in sub-cuticular connective tissue. H\&E. X400 


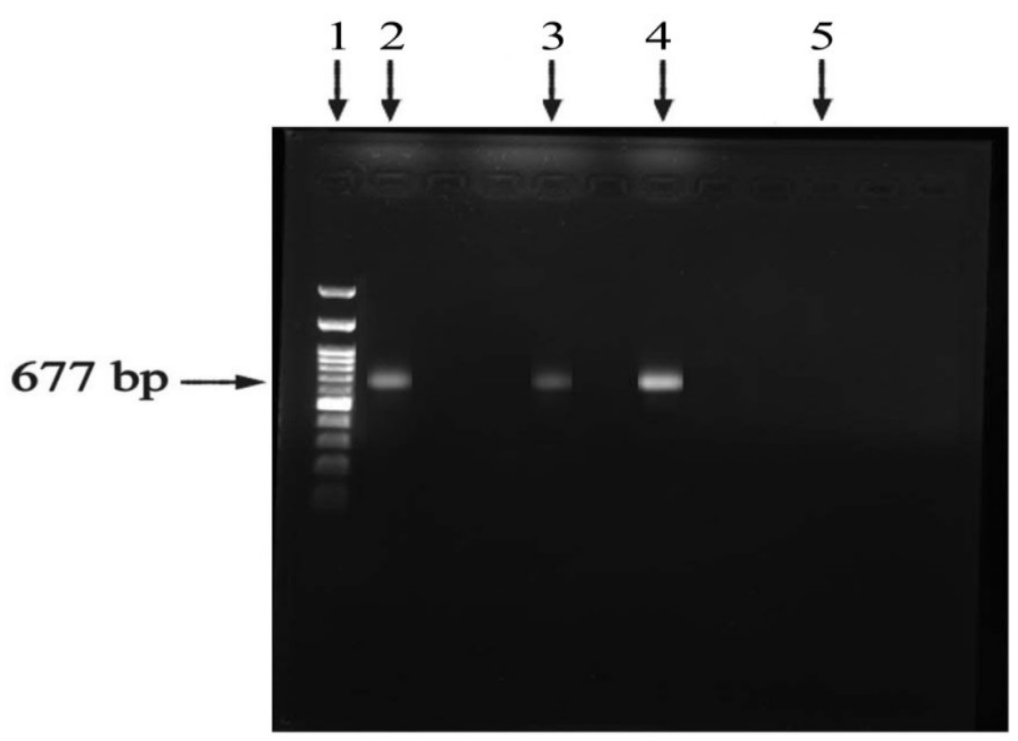

Figure 3: Agarose gel electrophoresis of PCR products of WSSV in different Shrimp species Lane 1 (DNA ladder); Lane 2 (WSSV in Penaeus semisulcatus); Lane 3 (WSSV in Aristeus antennatus); Lane 4 (WSSV in Penaeus Japonicus) and Lane 5 (Control-ve).

\section{Discussion}

White spot syndrome virus (WSSV) is a pathogen of major economic importance in cultured penaeid shrimp. The virus is not only affect shrimp but also occurs in other freshwater and marine crustaceans, including crabs and crayfish (Lo et al, 1996). The virus cause cumulative mortalities in infected populations may reach $100 \%$ within 2 to 10 days of the onset of clinical signs (Chou et al, 1995 and Lightner, 1996).

Little information on prevalence of white spot syndrome virus in shrimp aquaculture in Egypt is available. Although shrimp aquaculture are recently developed in Egypt, the virus infection of shrimp represent a major threats for shrimp farming so the prevention and control of white spot syndrome virus is a rational alternatives. The main goal of our study was to highlights on the disease occurrence in Egypt and to study the pathology of the disease in the most dominant shrimp species.

For this reasons 90 shrimps of three different shrimp species showed white spots in cuticle were collected from three different regions located in the east coast of Mediterranean Sea in Egypt. These results were confirmed by the data obtained by (Eissa et al, 2009 and Salama et al, 2008) whose detected WSSV among Egyptian shrimp for the first 
time in Egypt in shrimp samples collected from red sea and Mediterranean sea.

The current study revealed that, all the examined shrimp (three species) suffered from WSSV infection showed reddishness of the body and appendages of the affected shrimp followed by white spots initially circular spots in the cuticle. The cuticular spots of WSSV first appeared on the carapace and on the abdominal segments, and later on the shell of the whole body and ranged from minute to discs several millimetres in diameter, which may coalesce into large patches. These spots were most observed by removing the cuticle over the cephalothorax. These clinical signs may be attributed to WSSV infection may induce the dysfunction of the integument resulting in the accumulation of calcium salts within the cuticle and giving rise to white spots. Obtained results were nearly similar to those recorded by (Wang et al, 2002; Lotz and Soto, 2002 and $W u$ et al, 2005).

Data obtained in our study showed that many cases of the three studied shrimp species affected with WSSV exhibited brown-reddish coloration of the whole body with white spots distributed along the cuticle of carapace and cephalothorax, However, some deformities as broken appendages were found. These results were proven before due to expansion of the cuticular chromatophores and deposition of calcium in cuticle of infected shrimp (Chen et al, 2000).

The signs of the disease obtained by other researchers included: (I) The cuticle could be easily separated from the underlying epidermis, (2) The hepatopancreas became yellowish-white and was enlarged and fragile, (3) The hemolymph was thin and delayed or failed to coagulate, (4) The shrimp reduced feed intake or stopped feeding, followed by reduction in preening activity and locomotion, which were manifested by gill fouling and a weak response to stimulation, (5) Moribund shrimp usually showed reddish coloration of the body and they stayed at the pond edge or swam slowly at the water surface before finally sinking to the pond bottom, (6) High mortality rates of 70 to $100 \%$ usually occurred within a week after the emergence of gross signs (Wang, Y.G et al, 1999).

The developing mechanism of the characteristic white spots on the shell in P. Monodon was carried out by many workers and support our results. One of the features of this virus is the transformation of latent to patent stage. It has been noticed that the latent stage persists for longer months, and the transformation of latent to patent takes within hours under stressful conditions. Stresses could be crowding, high temperature, and oxygen depletion, ammonia toxicity at high $\mathrm{pH}$, hydrogen sulphide, very high and very low salinity and even periopod excision (Peng et al, 
1998; Kasomchandra et al, 1998).

In several epizootics of white spot viral infection, moderate softening of the exoskeleton has also been reported. It appears that the changes in the structural integrity of the exo and pro cuticle might be the reason for this syndrome. Cuticular epithelial cells have been reported as the target of the white spot syndrome virus as demonstrated by (Karunasagar et al, 1997). In the present study, histopathological observation of the outer exocuticle and the underlying procuticular layers of the integument were discernable in the infected state forming characteristic intranuclear inclusion bodies. The underlying epidermis which secretes the integument showed massive necrosis and nuclear hypertrophy.

The gills of WSSV infected shrimp (PCR +ve) showed massive disintegration and vacuolization in infected specimens. The gill filaments contained numerous lacunae occluded by hemocytes. The infection caused massive disintegration and generalized vacuolization with intranuclear inclusion bodies and the nuclei of the epithelial cells were hypertrophied. These major pathological changes observed in gills in our study have not been reported by the earlier researchers. (Karunasagar et al, 1997; Sudha et al, 1998; Rajendran et al, 1999).

The heart is a sac-like contractile structure, which lies immediately dorsoposterior to the hepatopancreas. In the infected shrimps hypertrophied nuclei characteristic of White Spot Virus could not be demonstrated in heart tissues. However, a generalized vacuolization of the tissue as a whole with characteristic intranuclear inclusions and constriction of muscle bundles along with increased infiltration of blood cell were seen. Regarding nuclear hypertrophy as a pathological change our observation matched with those of (Lo et al, 1997) as the nuclei remained close to normal size.

The hepatopancreas forms a large, glandular mass of tubules occupying much of the cephalothoracic cavity of shrimp. The tubules of hepatopancreas were ensheathed by thin connective tissue. In our data the hepatopancreas of WSSV infected shrimp exhibited vacuolization of the entire tissue as reported by (Wang et al, 1999). The four different cell types which line the hepatopancreatic tubules were not distinguishable in the moribund shrimps suggesting dysfunction of the organ. These findings correlated with that obtained by (Wang et al, 1997 and 1999).

Earlier studies revealed that the white spot virus grows in the myoepithelial cells of the hepatopancreatic sheath and the fibroblast of the connective tissues (Chang et al., 1996) and not in the hepatopancreatic tubular epithelial cells. Chang et al., (1996) reported 
lysis of some parts of hepatopancreas in the later stages of infection without detecting any virus due to the unhealthy state of the infected shrimp and also due to the autolysis of the infected tissue.

Histopathological examination of stomach of infected shrimp in our study showing hyperatrophy and hyaline degeneration in epithelium of the organ. Cuticular and subcuticular connective tissue cells of stomach wall showed intranuclear basophilic inclusion bodies. Our data are in confirmation with (Chang et al, 1996; Wang et al, 1999 and Perez, et al, 2005).

Hemocytic encapsulation and phagocytosis of infected and necrotic cells were observed among hamatopioteic tissues, which suggest that a protective response could have been stimulated among these shrimp. Relatively severe WSSV lesions in the lymphoid organ and hematopoietic tissues, Suggested that hemocytes are important in the shrimp's defense response.

WSSV contains a large doublestranded DNA of about $290 \mathrm{kbp}$, as evidenced from restriction-enzyme analysis (Yang et al, 1997). Based on the analysis of WSSV-specific sequences, it can be concluded that there is more than 50 types of non structural proteins in WSSV. This was further confirmed by analysis of WSSV structural proteins from different geographical isolates which showed differential profiles (Wang et al, 1999). The most antigenic type is VP28 capsid protein from which the primer sets were designed for PCR study (Lo et al, 1999 and Wang et al, 2000).

PCR has become the preferred method for measuring the exact number of DNA molecules, because it exceeds the sensitivity limits of classical methods such as Southern blot or dot blot hybridization (Tang and Lightner, 2000). PCR detection method is based on amplification of a target WSSV genome in shrimp samples together with primer sets targeting VP28 gene in a one-tube reaction. Our data indicated that visualization of predicted band at 677 bp compared to negative results in non infected tissues reflecting the presence of this gene in infected shrimp tissues. The predicted band of WSSV DNA are successfly observed in the three studied shrimp species (Penaeus Japonicus, Penaeus semisulcatus and Aristeus antennatus). These data are in accordance with that obtained by (Lo et al, 1996 and Wang et al, 1998).

In conclusion, the PCR based method for detection of WSSV DNA in clinical samples of infected shrimp, provides a sensitive tool for quantification of viral genomes as confirmed by histopathological lesions in three examined species of shrimp in three coastal Egyptian provinces.

\section{References}

Bell, T.A. and Lightner, D.V. (1988): A handbook of normal 
penaeid shrimp histology. World Aquaculture Society, Baton Rouge, LA.

Chang P.S.; Lo C.F.; Wang Y.C. and Kou G.H. (1996): Identification of white spot syndrome virus associated baculovirus (WSBV) target organs in the shrimp Penaeus monodon by in situ hybridization. Diseases of Aquatic Organisms 27, $131-139$.

Chen L.L.; Leu J.H.; Huang C.J.; Chou C.M.; Chen S.M.; Wang C.H.; Lo C.F. and Kou G.H. (2002): Identification of a nucleocapsid protein (VP35) gene of shrimp white spot syndrome virus and characterization of the motif important for targeting VP35 to the nuclei of transfected insect cells. Virology, 293, $44-53$.

Chou, H.Y.; Huang, C.Y.; Wang, C.H.; Chiang, H.C. and Lo, C.F. (1995): Pathogenicity of a baculovirus infection causing white spot syndrome in cultured penaeid shrimp in Taiwan. Dis. Aquat. Org. 23: 165 - 173 .

Eissa, I.A.M; Badran, A.F.H; Diab, A.S.; Saker, S.F.M and Ahmed, A.A (2009): Diagnosis of white spot syndrome virus(WSSV) among shrimp for the first time in Egypt. SCVMJ, VIX(1), 2009.

Escobedo-Bonilla, C.M.; AldaySanz, V.; Wille, M.; Sorgeloos, P.; Pensaert, M.B. and Nauwynck, H.J. (2008): A review on the morphology, molecular characterization, morphogenesis and pathogenesis of white spot syndrome virus. Journal of Fish Diseases $31,1-18$.

FAO (2008): Fishery and Aquaculture Statistics. FAO Year Book 2006. Food and Agriculture Organization of the United Nations, Rome, p57.

Flegel, T. W. (2006): Detection of major penaeid shrimp viruses in Asia, a historical perspective with emphasis on Thailand. Aquaculture $258,1-33$.

Karunasagar, I.; Otta, S.K. and Karunasagar, I. (1997): Histopathological and bacteriological study of white spot syndrome of Penaeus monodon along the west coast of India. Aquaculture 153, 9 - 13.

Kasornchandra, J.; Boonyaratpalin, S. and Itami, T. (1998): Detection of white spot syndrome in cultured penaeid shrimp in Asia: microscopic observation and polymerase chain reaction. Aquaculture 164, 243 251.

Lightner, D.V. (1996): A handbook of pathology and diagnostic procedures for diseases of penaeid shrimp. Baton Rouge, Louisiana, USA: World Aquaculture Society, 1996.

Lightner, D.V. (2003): Exclusion of specific pathogens for disease prevention in a penaeid shrimp biosecurity program. pp. 81-116 in: Lee, C.-S, and O'Bryen, P.J. (eds.) Biosecurity in Aquaculture Production Systems: Exclusion of Pathogens and Other Undesirables. 
The World Aquaculture Society, Baton Rouge, LA, USA.

Lo, C.F.; Leu, J-H.; Ho, C-H.; Chen, C-H.; Peng, S-E.; Chen, YT.; Chou, C-M.; Yeh, P-Y.; Huang, C-J.; Chou, H-Y.; Wang, C-H. and Kou, G-H. (1996): Detection of baculovirus associated with white spot syndrome (WSBV) in penaeid shrimps using polymerase chain reaction. Dis. Aquat. Org. 25, $133-141$.

Lo, C.F.; Ho, C.H.; Chen, C.H.; Liu, K.F.; Chiu, Y.L.; Yeh, P.Y.; Peng, S.E.; Hsu, H.C.; Liu, H.C.; Chang, C.F.; Su, M.S.; Wang, C.H. and Kou, G.H. (1997): Detection and tissue tropism of white spot syndrome baculovirus (WSBV) in captured brooders of Penaeus monodon with a special emphasis on reproductive organs. Diseases of Aquatic Organisms 30, $53-72$.

Lo, C. F.; Cheng, C. T. and Kou, G. H. (1999): PCR monitoring of cultured shrimp for white spot syndrome virus (WSSV) infection in grow out ponds, p. $281-286$.

Lotz, J. M. and Soto, M. A. (2002): Model of white spot syndrome virus (WSSV) epidemics in Litopenaeus vannamei. Diseases of Aquatic Organisms, 50, 199 209.

Mayo, M. A. (2002): A summary of taxonomic changes recently approved by ICTV. Archives of Virology, 147, 1655 - 1663.

Peng, S.E.; Lo, C.F.; Ho, C.H.; Chang, C.F. and Kou, G.H. (1998): Detection of white spot baculovirus (WSBV) in giant fresh water prawn; Macrobrachium rosenbergii; using polymerase chain reaction. Aquaculture 164, 253 262.

Pérez, F.; Volckaert, F.A.M. and Calderón, J. (2005): Pathogenicity of white spot syndrome virus on postlarvae and juveniles of Penaeus (Litopenaeus) vannamei. Aquaculture 250, 586 - 591.

Pillai, N.G.K.; Katiha, P.K. (2004): Evolution of fisheries and aquaculture in India, p240. Central Marine Research Institute, Kochi, India.

Pradeep, B.; Karunasagar, I. and Karunasagar, I. (2009): Fitness and virulence of different strains of white spot syndrome virus. Journal of Fish Diseases, 32: $801-805$.

Rajendran, K.V.; Vijayan, K.K.; Santiago, T.C. and Krol, R.M. (1999): Experimental host range and histopathology of white spot syndrome virus (WSSV) infection in shrimp, prawns, crayfish and lobsters from India. Journal of Fish Diseases 22, 183 - 191.

Rosenberry B, (2001): World shrimp farming 2001, In: Shrimp News International, USA Rosenberry B, (Ed.), pp.324. San Diego, CA, USA

Rudloe, Jack and Rudloe, Anne (2009): Shrimp: the endless quest for pink gold FT Press. pp. $15-26$.

Salama, A.A; Diab, A.S.; Abd ElSamie, A.H. and Abdel-Wahab, A. M. (2008): Isolation and Identification of White Spot Syndrome Virus. Zag. Vet. J. 
(ISSN. 1110-1458) Vol.36, No. 4 pp. $105-113$.

Sudha, P.M.; Mohan, C.V. and Shankar, K.M. (1998): Relationship between white spot syndrome virus infection and clinical manifestation in Indian cultured penaeid shrimp. Aquaculture, 167: 95 - 101.

Tang, K.F.J.; Lightner, D.V. (2000): Quantification of white spot syndrome virus DNA through a competitive polymerase chain reaction. Aquaculture 189: $11-21$.

Van Hulten, M.C.; Witteveldt, J.; Peters, S.; Kloosterboer, N.; Tarchini, R.; Fiers M.; Sandbrink, H.; Klein-Langhorst, R. and Vlak, J.M. (2001): The white spot syndrome virus DNA genomic sequence. Virology, 286: 7 -22 .

Vijayan, K.K. and Alavandi, S.V. (2005): Histological techniques as diagnostic tool in shrimp diseases. Central Institute of Brackish water Aquaculture, special publication, No. 26, $44-50$.

Wang, Y.G.; Lee, K.L.; Najiah, M.; Shariff, M. and Hassan, M.D. (2002): A new bacterial white spot syndrome (BWSS): in cultured tiger shrimp Penaeus monodon and its comparison with white spot syndrome (WSS): caused by virus. Dis. Aquat. Org.; 41 (1): $9-18$.

Wang, Q.; Poulos, B.T. and Lightner, D.V. (2000): Protein analysis of geographic isolates of shrimp white spot syndrome virus. Archives of Virology 145, 263 274.
Wang, Q.; White, B.L.; Redman, R.M. and Lightner, D.V. (1999): Per os challenge of Litopenaeus vannamei postlarvae and Farfantepenaeus duorarum juveniles with six geographic isolates of white spot syndrome virus. Aquaculture 170, 179 - 194.

Wang, Y.G.; Hassan, M.D.; Shariff, M.; Zamri, S.M. and Chen, X., (1999): Histopathology and cytopathology of white spot syndrome virus (WSSV) in cultured P. monodon from peninsular Malaysia with emphasis on pathogenesis and the mechanism of white spot formation. Disease of Aquatic Organisms, 39: 1-11.

Wang, Y.C.; Lo, C.F.; Chang, P.S. and Kou, G.H. (1998): Experimental infection of white spot baculovirus in some cultured and wild decapods in Taiwan. Aquaculture 164, 221 - 231.

Wang, Y.C.; Lo, C.F.; Chang, P.S. and Kou, G.H. (1998a): Experimental infection of white spot baculovirus in some cultured and wild decapods in Taiwan. Aquaculture 164, $221-231$.

Wang, C.S.; Tang, K.F.J.; Kou, G.H and Chen, S.N. (1997): Light and electron microscopic evidence of white spot disease in the giant tiger shrimp, Penaeus monodon (Fabricius), and Kuruma shrimp, Penaeus japonicus (Bate), cultured in Taiwan. Journal of Fish Diseases 20: $323-331$.

Wu, W.; Wang, L. and Zhang, X. (2005): Identification of white spot syndrome virus (WSSV) envelope 
proteins involved in shrimp Yang, F.; He, J.; Lin, X.; Li, Q.; infection. Virology 332, 578 - 583. Pan, D.; Zhang, X. and Xu, X.

Yang, F.; Wang, W.; Chen, R.Z. and $X u, X$. (1997): A simple and efficient method for purification of prawn baculovirus DNA. Journal of Virological Methods 67, $1-4$.

(2001): Complete genome sequence of the shrimp white spot bacilliform virus. Journal of Virology 75 , $11811-11820$.

الكثف عن مرض البقع البيضاء في الجمبرى : فحص الصفة التثريحية المرضية وتفاعل البلمرة

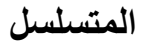

محمد سعيد الثهيدى ${ }^{3}$ رفعت محمد الجمل3 ، أمينة على الاسوقى 2 ، رندا يسرى ثابت، شهيرة عبدالفتاح عبدالوهاب 1 ، ،حمل مصطفى عبدالدايم1 13

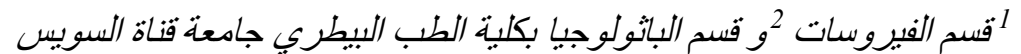

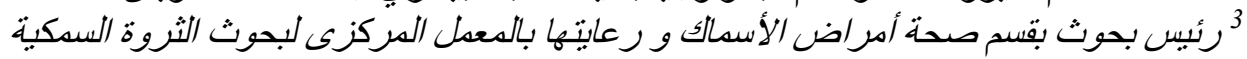

بالعباسة

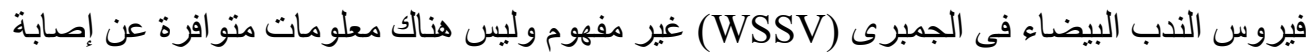

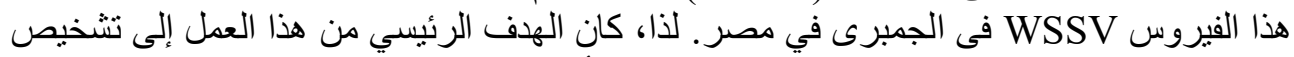
WSSV

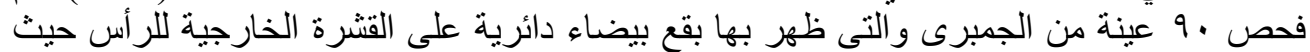

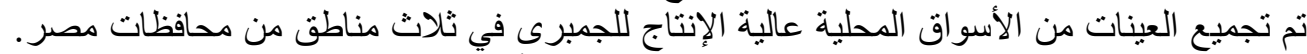

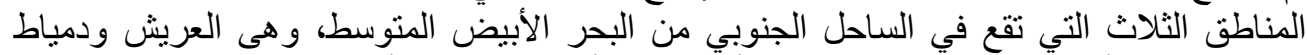

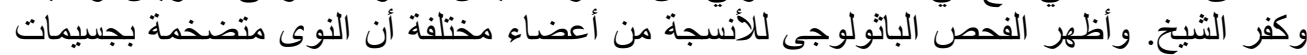

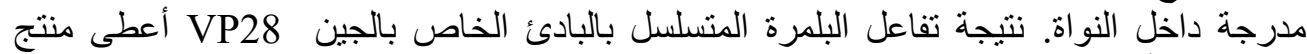
متوقع بخط أبيض على الجيل عند TVV قاعدة نيتروجينية باستخدام الجيل للفصل الكهربائى. 